\title{
ANAK KITA MASA DEPAN KITA PEMBERDAYAAN IBU RUMAH TANGGA PERUMAHAN PERMATA PAMULANG
}

Retno Japanis Permatasari*, Cornelia Dumarya Manik,Kharisma Danang Yuangga

Dosen Fakultas Ekonomi. Universitas Pamulang

Email* : anis jepang88@rocketmail.com

\begin{abstract}
ABSTRAK
Tulisan ini bertujuan untuk mengetahui sejauh mana keberhasilan upaya pemberdayaan orang tua untuk perkembangan anak di masa yang akan datang

Teknik pendekatan dilakukan dengan metode seminar dan penyuluhan secara langsung

Hasil kegiatan dapat membuka wawasan dari para ibu rumah tangga, sehingga dapat membantu dan meningkatkan kesehatan buah hatinya dengan meningkatkan kecukupan gizi mereka..
\end{abstract}

\section{Kata Kunci :kesehatan anak, kecukupan gizi}

\section{PENDAHULUAN}

Kegiatan pengabdian masyarakat merupakan salah satu Tri Dharma Perguruan Tinggi Selain Pendidikan dan Penelitian, sesuai undang-Undang RI Nomor 20 Tahun 2003 tentang Sistem Pendidikan Nasional, pada Pasal 20 ayat 2 dinyatakan: "Perguruan Tinggi berkewajiban menyelenggarakan pendidikan, penelitian dan pengabdian masyarakat". Pada Pasal 24 ayat 2 disebutkan:" Perguruan tinggi memiliki otonomi untuk mengelola sendiri lembaganya sebagai pusat penyelenggaraan pendidikan tinggi, penelitian ilmiah, dan pengabdian masyarakat".

Perkembangan anak sangat erat kaitannya dengan pemenuhan gizi anak, sebagai orang tua seyogyanya kita harus memperhatikan perkembangan anak dari mulai pemenuhan kebutuhan pangan yang bergizi, pemenuhan kebutuhan sandang yang sehat dan pemenuhan kebutuhan tempat tinggal yang layak, lingkungan yang mendukung serta pendidikan yang berkualitas.

Sasaran kegiatan Pengabdian kepada masyarakat (PKM) ini adalah dengan mengajak para para orang tua untuk mengikuti Talk Show atau penyuluhan dengan rangkaian kegiatan seminar dan tanya jawab seputar anak dengan memberdayakan orang tua dengan tema "Anak Kita Masa Depan Kita"

\section{RUMUSAN MASALAH}

Berdasarkan latar belakang diatas dapat dirumuskan permasalahan sebagai berikut: Bagaimana upaya pemberdayaan orang tua untuk perkembangan anak di amsa yang akan datang? 


\section{TUJUAN}

Tujuan yang ingin dicapai dalam kegiatan ini adalah : Untuk mengetahui sejauh mana keberhasilan upaya pemberdayaan orang tua untuk perkembangan anak di masa yang akan datang.

\section{KEGIATAN}

Sasaran dari program Pengabdian Masyarakat yang akan kami ini adalah ibu rumah tangga Perumahan Permata Pamulang, Jalan Betet 3, Blok A4, No 12, Pamulang, Tangerang Selatan. Dengan jumlah peserta pelatihan kurang lebih 50 orang.

Tempat, Waktu, Pelaksanaan dan Tema Kegiatan

Hari : Selasa s/d Kamis

Tanggal/Bulan $\quad: 5 \mathrm{~s} / \mathrm{d} 7$ Juni 2018

Waktu

: Pukul 09.00 - 12.00 WIB

Tempat

: Balai Warga Perumahan Permata Pamulang, Jalan Betet 3

Bok A4, No. 12, Pamulang, Tangerang Selatan.

\section{APLIKASI}

\section{A. Perkembangan Anak Usia Balita}

Tahap perkembangan anak yang paling kritis berlangsung di masa usia dini, yaitu antara usia 0 hingga 6 tahun. Perkembangan yang terjadi pada anak di periode ini berlangsung pesat dibandingkan fase usia lain karena perkembangan otak anak mencapai $80 \%$ pada tiga tahun pertama hidupnya. Pada saat si Kecil berusia 5 tahun, perkembangan otaknya sudah mencapai $90 \%$, sedangkan sisanya berkembang dalam kecepatan yang lebih lambat hingga ia mencapai usia dewasa (18 tahun).

Penting untuk dipahami bahwa pertumbuhan dan perkembangan pada anak tidak dapat dipisahkan. Yang dimaksud dengan pertumbuhan adalah perubahan yang bersifat kuantitatif, contohnya tinggi dan berat badan, serta ukuran tulang maupun organ tubuh lain yang bertambah besar seiring dengan pertambahan usia si Kecil. Sementara yang dimaksud dengan perkembangan adalah bertambahnya kemampuan (skill) struktur dan fungsi tubuh yang lebih kompleks, dalam pola yang teratur dan dapat diramalkan, sebagai hasil dari proses pematangan/maturitas.

Perkembangan anak usia dini meliputi perkembangan kognitif, bahasa, motorik, emosi, dan perilaku. Secara umum, setiap anak mengikuti pola perkembangan yang sama, tetapi kecepatannya berbeda. Perbedaan tersebut dipengaruhi oleh kondisi biologis/genetik, nutrisi, lingkungan, serta interaksi antara anak dengan orang tua/pengasuh. Berikut tiga periode penting perkembangan anak usia dini yang perlu Mam ketahui.

Kecukupan Gizi Pada Gizi (nutrients) merupakan ikatan kimia yang diperlukan tubuh untuk melakukan fungsinya, yaitu menghasilkan energi, membangun dan memelihara jaringan, serta mengatur proses-proses kehidupan. 
Disamping untuk kesehatan, gizi dikaitkan dengan potensi ekonomi seseorang, karena gizi berkaitan dengan perkembangan otak, kemampuan belajar, dan produktivitas kerja (Almatsier, 2002).

Konsumsi makanan merupakan faktor utama yang berperan terhadap status gizi seseorang. Metode pengukuran konsumsi pangan untuk individu, antara lain metode recall 24 jam, metode estimated food recall, metode penimbangan makanan (food weighing), metode dietary history, dan metode frekuensi makanan (food frequency).

Angka Kecukupan Gizi (AKG) adalah banyaknya zat-zat minimal yang dibutuhkan seseorang untuk mempertahankan status gizi yang adekuat. AKG yang dianjurkan didasarkan pada patokan berat badan untuk masing-masing kelompok umur, jenis kelamin, tinggi badan, berat badan, kondisi khusus (hamil dan menyusui) dan aktivitas fisik (Almatsier, 2002).

\section{Energi}

Energi dalam makanan berasal dari nutrisi karbohidrat, protein, dan lemak. Setiap gram protein menghasilkan 4 kalori, lemak 9 kalori dan karbohidrat 4 kalori. Distribusi kalori dalam makanan anak yang dalam keseimbangan diet (balanced diet) ialah $15 \%$ berasal dari protein, 35\% dari lemak dan 50\% dari karbohidrat. Kelebihan energi yang tetap setiap hari sebanyak 500 kalori, dapat menyebabkan kenaikan berat badan 500 gram dalam seminggu (Soediaoetama, 2004)

Tabel Angka Kecukupan Energi Untuk Anak Balita

\begin{tabular}{|c|c|c|}
\hline Golongan umur (tahun) & Kecukupan Energi & Kal/kg BB/hari \\
\hline 1 & 990 & 110 \\
\hline $1-3$ & 1200 & 100 \\
\hline $4-5$ & 1620 & 90 \\
\hline
\end{tabular}

Sumber : Soediaoetama, 2004

\section{Protein}

Nilai gizi protein ditentukan oleh kadar asam amino esensial. Akan tetapi dalam praktek sehari-hari umumnya dapat ditentukan dari asalnya. Protein hewani biasanya mempunyai nilai yang lebih tinggi bila dibandingkan dengan protein nabati. Protein telur dan protein susu biasanya dipakai sebagai standar untuk nilai gizi protein.

Nilai gizi protein nabati ditentukan oleh asam amino yang kurang (asam amino pembatas), misalnya protein kacang-kacangan. Nilai protein dalam makanan orang Indonesia sehari-hari umumnya diperkirakan $60 \%$ dari pada nilai gizi protein telur (Soediaoetama, 2004). 
Tabel Angka Kecukupan Protein Anak Balita (gr/kgBB sehari )

\begin{tabular}{|c|c|}
\hline Umur (tahun) & gram / hari \\
\hline 1 & 1,27 \\
\hline 2 & 1,19 \\
\hline 3 & 1,12 \\
\hline 4 & 1,06 \\
\hline 5 & 1,01 \\
\hline
\end{tabular}

Sumber : Soediaoetama, 2004

\section{Lemak}

Lemak merupakan komponen struktural dari semua sel-sel tubuh, yang dibutuhkan oleh ratusan bahkan ribuan fungsi fisiologis tubuh (McGuire \& Beerman, 2011).

Lemak terdiri dari trigliserida, fosfolipid dan sterol yang masing-masing mempunyai fungsi khusus bagi kesehatan manusia. Sebagian besar (99\%) lemak tubuh adalah trigliserida. Trigliserida terdiri dari gliserol dan asam-asam lemak. Disamping mensuplai energi, lemak terutama trigliserida, berfungsi menyediakan cadangan energi tubuh, isolator, pelindung organ dan menyediakan asam-asam lemak esensial (Mahan \& Escott-Stump, 2008).

\section{Tabel Tingkat Kecukupan Lemak Anak Balita}

\begin{tabular}{|l|l|}
\hline Umur (tahun) & Gram \\
\hline 0-5 bulan & 31 \\
\hline 6-11 bulan & 36 \\
\hline 1-3 tahun & 44 \\
\hline 4-6 tahun & 62 \\
\hline
\end{tabular}

Sumber : Hardinsyah, 2012

\section{Vitamin dan Mineral}

Pada dasarnya dalam ilmu gizi, nutrisi atau yang lebih dikenal dengan zat gizi dibagi menjadi 2 macam, yaitu makronutrisi dan mikronutrisi. Makronutrisi terdiri dari protein, lemak, karbohidrat dan beberapa mineral yang dibutuhkan tubuh dalam jumlah yang besar. Sedangkan mikronutrisi (mikronutrient) adalah yang diperlukan tubuh dalam jumlah sangat sedikit (dalam ukuran miligram sampai mikrogram), seperti vitamin dan mineral (Sandjaja, 2009).

Menurut Almatsier (2001), vitamin adalah zat-zat organik kompleks yang dibutuhkan tubuh dalam jumlah sangat kecil. Vitamin dibagi menjadi 2 kelompok yaitu vitamin yang larut dalam air (vitamin B dan C) dan vitamin yang tidak larut dalam air (vitamin A, D, E dan K). Menurut Soerdarmo dan Sediaoetama (1977), satuan untuk vitamin yang larut dalam lemak dikenal dengan Satuan Internasional 
(S.I) atau I.U (International Unit). Sedangkan yang larut dalam air maka berbagai vitamin dapat diukur dengan satuan milligram atau mikrogram.

Mineral merupakan bagian dari tubuh dan memegang peranan penting dalam pemeliharaan fungsi tubuh, baik pada tingkat sel, jaringan, organ maupun fungsi tubuh secara keseluruhan, berperan dalam berbagai tahap metabolisme, terutama sebagai kofaktor dalam aktivitas enzim-enzim (Almatsier, 2001).

Tabel Tingkat Kecukupan Vitamin dan Mineral Anak Balita

\begin{tabular}{|c|c|c|c|c|c|}
\hline Umur & $\begin{array}{c}\text { Kalsium } \\
(\mathbf{m g})\end{array}$ & $\begin{array}{c}\text { Fosfor } \\
(\mathbf{m g})\end{array}$ & $\begin{array}{c}\text { Zat besi } \\
(\mathbf{m g})\end{array}$ & $\begin{array}{c}\text { Vitamin A } \\
(\mathbf{R E})\end{array}$ & $\begin{array}{c}\text { Vitamin C } \\
(\mathbf{m g})\end{array}$ \\
\hline $\begin{array}{c}0-5 \\
\text { bulan }\end{array}$ & 200 & 100 & 0,5 & 375 & 40 \\
\hline $\begin{array}{c}6-11 \\
\text { bulan }\end{array}$ & 400 & 225 & 7 & 400 & 40 \\
\hline $\begin{array}{c}1-3 \\
\text { tahun }\end{array}$ & 500 & 400 & 8 & 400 & 40 \\
\hline $\begin{array}{c}4-6 \\
\text { tahun }\end{array}$ & 500 & 400 & 9 & 450 & 45 \\
\hline
\end{tabular}

Sumber : Angka Kecukupan Gizi, 2004

\section{B. Perkembangan Kognitif, Motorik Dan Personal-Sosial Pada Anak}

Perkembangan anak usia dini meliputi perkembangan kognitif, bahasa, motorik, emosi, dan perilaku. Secara umum, setiap anak mengikuti pola perkembangan yang sama, tetapi kecepatannya berbeda. Perbedaan tersebut dipengaruhi oleh kondisi biologis/genetik, nutrisi, lingkungan, serta interaksi antara anak dengan orang tua/pengasuh. Berikut tiga periode penting perkembangan anak usia dini yang perlu Mam ketahui.

\section{Perkembangan Anak pada Periode Bayi (usia 0-12 bulan)}

a. Perkembangan kognitif

Si Kecil melakukan kontak mata dan menangis untuk menunjukkan kebutuhan, senang bermain, mengeksplorasi benda menggunakan tangan dan mulut, tertarik pada bagian-bagian tubuhnya, dan senang mengeksplorasi sekitarnya.

b. Perkembangan motorik

Pada usia 0-3 bulan, si Kecil belajar mengangkat kepala dan menggerakkannya ke kiri dan kanan. Pada usia 6 bulan, ia mampu menggenggam, meraih benda dalam jangkauannya, belajar merangkak, dan berguling. Pada usia 12 bulan, si Kecil mampu mengulurkan tangan untuk meraih mainan, memasukkan benda ke dalam mulut, duduk dan berdiri sendiri, dan berjalan sambil berpegangan pada tembok atau perabot. 


\section{c. Perkembangan personal-sosial}

Pada usia 1-3 bulan, ikatan bonding antara orang tua dan bayi dimulai. Si Kecil tersenyum, menatap wajah Mam, senang melihat orang yang dikenal, senang mendengarkan musik, dan dapat bereaksi terkejut pada suara keras. Pada usia 3-6 bulan, kedekatan antara bayi dan orang tua mulai terjalin. Si Kecil lebih sering tersenyum spontan, tertawa keras, dan banyak berceloteh. Pada usia 6-12 bulan, si Kecil senang bermain tepuk tangan atau "Cilukba", merespon bila namanya dipanggil, dapat melambaikan tangan, memahami perintah sederhana, dan senang mengeksplorasi sekitarnya.

\section{Perkembangan Anak pada Periode Batita (usia 1-3 tahun)}

a. Perkembangan kognitif

Si Kecil kini telah mampu membedakan bentuk dan warna, senang bermain pura-pura, senang membantu Mam mengerjakan pekerjaan rumah tangga, dapat menunjuk bagian tubuhnya saat diminta, dan dapat menggabungkan 2-3 kata menjadi kalimat. Saat berusia 3 tahun, umumnya anak dapat menyebut nama, umur, dan tempat tinggalnya.

b. Perkembangan motorik

Pada periode ini, si Kecil mampu berjalan dengan baik tanpa terhuyung-huyung, berjalan mundur, serta naik turun tangga sendiri. Kemampuan motorik halus pada perkembangan anak 15 bulan pun perlu dicermati, yaitu si Kecil mampu menumpuk kubus dan memasukkannya ke dalam kotak. Di usia 3 tahun, ia mampu melompat dengan kedua kaki, bermain sepeda roda tiga, dan mencorat-coret.

\section{c. Perkembangan personal-sosial}

Memasuki tahun kedua hidupnya, si Kecil dapat menunjukkan apa yang diinginkan dengan menunjuk (tanpa menangis atau merengek) dan senang meniru aktivitas di rumah. Perkembangan anak 15 bulan di antaranya mulai tertarik makan dan minum sendiri dan belajar berbagi mainan dengan anak lain. Memasuki usia 3 tahun, si Kecil mampu melepas pakaiannya sendiri, senang menceritakan pengalaman baru, dan senang bermain dengan anak lain.

3. Perkembangan Anak pada Periode Prasekolah (usia 4-6 tahun)

a. Perkembangan kognitif

Kemampuan berpikir si Kecil di usia prasekolah ini semakin kompleks. Kini, ia sudah dapat memakai baju, celana, dan sepatu sendiri. Perkembangan anak usia 5 tahun lainnya yaitu, bisa mengikuti aturan permainan, mengerti arti lawan kata, mengenal angka, mampu berhitung, mengungkapkan simpati, dan sedang mengembangkan keterampilan membaca dengan baik. 
b. Perkembangan motorik

Selain pandai melompat-lompat dan berdiri dengan satu kaki, si Kecil juga kini sudah bisa menari lho, Mam. Bukan hanya itu, kemampuan motorik halusnya pun mengalami kemajuan karena umumnya anak usia 4-6 tahun sudah masuk prasekolah (playgroup atau Taman Kanak-kanak). Ia mampu menggambar tanda silang, lingkaran, segi empat, dan beberapa bagian tubuh.

c. Perkembangan personal-sosial

Anak usia prasekolah senang bermain dengan anak sebayanya, namun, di sisi lain juga suka cekcok dengan teman-temannya. Jadi, jangan heran bila si Kecil sering ingin terlihat mandiri, gemar mencari pengalaman baru, dan banyak bertanya ya, Mam. Semua perilaku itu wajar karena merupakan bagian dari perkembangan anak usia 5 tahun.

Idealnya, setiap orang tua memahami tahapan perkembangan anak di masa usia dini agar dapat memantau perkembangan si Kecil secara saksama. Dengan begitu, potensi gangguan perkembangan sekecil apa pun pada si Kecil dapat cepat terdeteksi dan dilakukan penanganan sedini mungkin sehingga proses tumbuh kembang yang optimal dapat tetap tercapai.

\section{STRATEGI}

Dalam penyuluhan ini strategi yang dilakukan adalah dengan metode talk show atau pemaparan, seminar secara langsung dan tanya jawab

\section{PENUTUP}

Dengan ada nya kegiatan ini menjadikan para ibu rumah tangga di lingkungan Perumahan Permata Pamulang dapat mengetahui dan meningkatkan kecukupan gizi buah hati nya.

Selama kegiatan berlangsung peserta penyuluhan memberikan tanggapan yang baik, hal ini dapat dilihat dari dukungan mereka dalam setiap kegiatan yang di adakan.

Selain itu harapan kami dengan pengabdian ini dapat membuka wawasan dari para ibu rumah tangga, sehingga dapat membantu dan meningkatkan kesehatan buah hatinya dengan meningkatkan kecukupan gizi mereka.

\section{DAFTAR PUSTAKA}

http://sayangianak.com/tahap-perkembangan-anak-0-5-tahun-tahapperkembangan-0-11-bulan/

https://www.dictio.id/t/bagaimanakah-kebutuhan-gizi-nutrisi-pada-balita/12058/3

https://hellosehat.com/parenting/perkembangan-balita/pertumbuhanperkembangan-balita/ 


\section{DOKUMENTASI FOTO KEGIATAN}
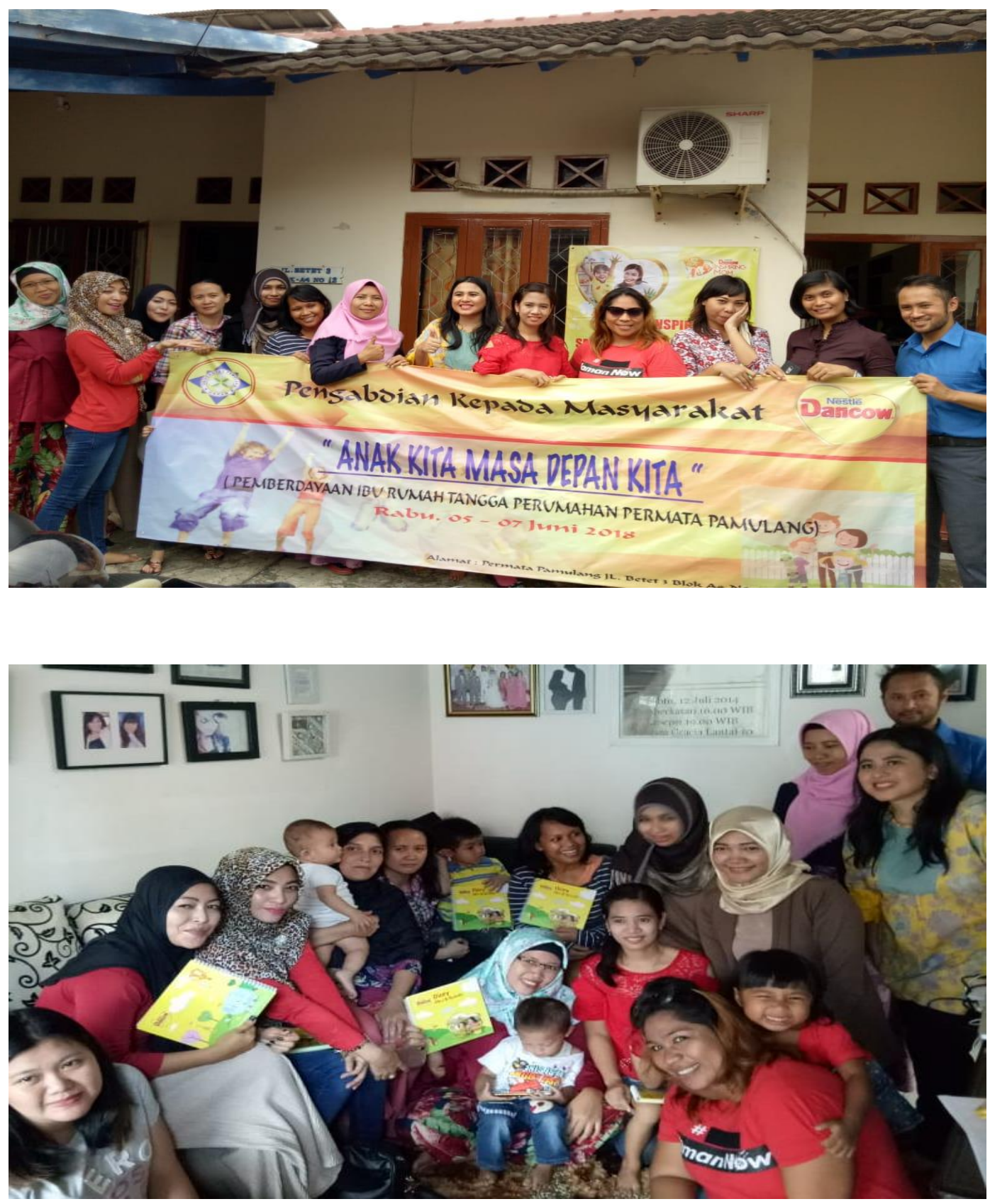